\title{
Test Of Antioxidant And Antibacterial Activity Of Ethanol Extract Of Andaliman Fruit (Zanthoxylum Acanthopodium Dc.) With Dpph (1.1-Diphenyl-2- Picrylhydrazil) Trapping Method And Minimum Inhibitory Concentration
}

\author{
Ira Syaputri $^{1}$, Ermi Girsang ${ }^{2 *}$, Linda Chiuman ${ }^{3}$ \\ 1,2,3 Program Study Master Of Biomedic Science Faculty Of Medicine \\ Universitas Prima Indonesia Medan, North Sumatera, Indonesia \\ ${ }^{*}$ Corresponding author: \\ Email: ermigirsang@unprimdn.ac.id
}

\begin{abstract}
.
Utilization of bioavailability according to World Health Organization (WHO) records is very large, it is estimated that almost $80 \%$ of mankind, especially in developing countries, still use plants as medicinal ingredients to maintain their health (Nugraheni, 2007). Andaliman (Zanthoxylum acanthopodium DC.) which belongs to the Rutaceae tribe which is one of the plants known to the Batak community, is classified as a wild plant and is a typical plant of Province North Sumatra. The method used in this research is experimental research. The research included collecting and processing andaliman fruit, making simplicia, making ethanol extracts, and examining antioxidant activity tests using the DPPH free radical scavenging method (1,1-diphenyl-2-picrylhydrazil) and antibacterial activity using the minimum inhibitory concentration method. The results of the antibacterial activity test of the ethanolic extract of andaliman fruit showed that the extract had antibacterial activity in the moderate category at a concentration of $300 \mathrm{mg} / \mathrm{ml}$ with an inhibition zone of $10.17 \mathrm{~mm}$ for Staphylococcus aureus bacteria and a moderate category for Staphylococcus epidermidis bacteria with an inhibition zone of $10.80 \mathrm{~mm}$. The ethanol extract of andaliman fruit can inhibit Staphylococcus aureus and Staphylococcus epidermidis, effective at a concentration of 300 $\mathrm{mg} / \mathrm{ml}$ with inhibitory diameters of $10.17 \mathrm{~mm}$ and $10.80 \mathrm{~mm}$, respectively.
\end{abstract}

Keywords: Andaliman fruit, antioxidants, DPPH, Staphylococcus aureus, and Staphylococcus epidermidis.

\section{INTRODUCTION.}

Utilization of bioavailability according to World Health Organization (WHO) records is very large, it is estimated that almost $80 \%$ of mankind, especially in developing countries, still use plants as medicinal ingredients to maintain their health (Nugraheni, 2007).In general, plants produce secondary metabolites that can be used to treat various types of diseases. The secondary metabolite compounds are alkaloids, flavonoids, saponins, tannins, steroids, and triterpenoids (Harborne, 1987). The ability of a plant is supported by the secondary metabolites contained in it. Climatic factors which include air temperature, sunlight, air humidity, and wind and soil conditions greatly affect the plant growth process to the variation of secondary metabolites contained.The effect of the material is closely related to the chemical compounds contained in the material. Andaliman plants contain terpenoid compounds (Wijaya, 1999), phenols, and steroids (Suryanto, et al., 2008). Phenol compounds are bioactive components that are toxic to predatory animals (Robinson, 1995). Several studies have shown that andaliman fruit extract has anti-inflammatory activity, immunostimulant effects, and antioxidant compounds in spices can also trigger the immune system, especially anticancer activity (Siregar, 2003).Based on several studies on medicinal plants, it was reported that many medicinal plants contain large amounts of antioxidants. The antioxidant effect is mainly due to the presence of phenolic compounds such as flavonoids and phenolic acids. Usually, the compounds that have antioxidant activity are phenolic compounds that have hydroxyl groups distributed in the ortho and para positions concerning the $-\mathrm{OH}$ and $-\mathrm{OR}$ groups (Praptiwi, et al., 2006). 
Antioxidants function to overcome or neutralize free radicals so that it is hoped that by giving these antioxidants the aging process is inhibited and can prevent damage to the body from the onset of degenerative diseases. The role of antioxidants is very important in neutralizing and destroying free radicals that can cause cell damage and also damage biomolecules in the body which can eventually trigger degenerative diseases. The selection of natural antioxidants is now starting to become a public concern because side effects have been found from the use of synthetic antioxidants in the form of poisoning and are carcinogenic if used for a long time and in excessive amounts (Zuhra, 2008).Antibacterial is a natural or synthetic compound that has the effect of suppressing or inhibiting bacterial growth. Bacteria can enter, multiply and cause infectious diseases. One of the parts of the body that is most often infected by bacteria in the digestive tract. Cholera, diarrhea, and gastroenteritis are digestive tract infections that are quite common in the wider community due to bacterial contamination of food and lack of sanitation (Anorital and Andayasari, 2011).Andaliman (Zanthoxylum acanthopodium DC.) which belongs to the Rutaceae tribe which is one of the plants known to the Batak community, is classified as a wild plant and is a typical plant of North Sumatra Province (Tensiska, et al., 2003). The Batak people have long used andaliman as a spice in various types of cuisine. Although this plant is relatively rare, butaliman fruit is relatively easy to find in traditional markets (Siregar, 2003). According to Siregar (2003) states that andaliman contains phenolic compounds, monoterpenes, and sesquiterpenes as well as quinones. According to Wijaya (1999), this plant species is known for its essential oil which is a group of terpenoid compounds. Based on its chemical content and physiological activity, the use of andaliman can be increased, not longer just a cooking spice, but also preservatives, medicinal ingredients and supplements, and vegetable pesticides (Siregar, 2003). According to Wijaya, et al., (1999) stated that the crude extract of andaliman fruit has also been reported to have physiological activity as an antioxidant and antimicrobial.Traditionally, andaliman fruit is widely used as an aromatic ingredient, tonic, appetite stimulant, medicine for stomach pain, and diarrhea.

Indian people use andaliman fruit to treat paralysis and various skin diseases, such as boils and leprosy. Andaliman fruit is also used as a cooking spice in North Sumatra, especially North Tapanuli (Suryanto, et al., 2004; Hynniewta, et al., 2008; Sirait, et al., 1991). Plants from the Zanthoxylum genus contain a lot of hydroquinone phenols, flavonoids, steroids/triterpenoids, tannins, glycosides, essential oils, alkaloids, coumarins, lignans, amides, and terpenes (Parhusip, 2006; Fernandes, et al., 2009; Hu, et al., 2006; Cui, et al., 2008; Chen, et al., 2007).Several studies have reported the potential of andaliman as an antimicrobial, antioxidant, anti-inflammatory, xanthine oxidase inhibitor, and cytotoxic (Kristanty and Suriawati, 2015). Other studies have also reported the antibacterial activity of andaliman extract against food pathogenic bacteria such as Bacillus cereus, Escherichia coli, Staphylococcus aureus, and Salmonella typhimurium (Parhusip et al., 2005). Based on the description above and some related literature, the researchers are interested in researching antioxidant activity using the DPPH method and antibacterial using the Minimum Inhibitory Concentration (MIC) method from Andaliman fruit (Zanthoxylum acanthopodium DC.). Based on the description of the background above, the formulation of the problem in this study is how is the antioxidant activity with the DPPH method (2,2-diphenyl-1-picrylhydrazil) and antibacterial using the Minimum Inhibitory Concentration (MIC) method against Staphylococcus aureus and Staphylococcus epidermidis on andaliman fruit (Zanthoxylum acanthopodium DC.).

\section{LITERATURE REVIEW.}

\subsection{Plant Description}

One of the typical spice plants found in North Sumatra is andaliman which is found growing wild in the Tapanuli area at 1500 meters above sea level at a temperature of $15-180 \mathrm{C}$, this plant is spread among others in northern India, Nepal, East Pakistan, Myanmar, Thailand. and China (Kristanty and Suriawati, 2015).

\section{https://ijhp.net}




\subsection{Plant Morphology}

Andaliman is an upright shrub with a height of 3-8 m, stems and branches are reddish, grooved, downy and thorny. Andaliman fruit is small round in shape, the pericarp is dark green to reddish and the color of the seeds is black, when bitten gives off a fragrant aroma, and has a sharp and distinctive bitter taste, and can stimulate saliva production. The fruit includes true fruit with a diameter of 3-4 mm consisting of one flower with many ovules, each of which is free and then grows into a fruit but gathers on one stalk. The length of the flower is $3 \mathrm{~mm}$. The leaves are compound leaves with a length of 2-25 cm, 1-6 pairs of leaflets with short stalks, serrated leaf edges, pointed leaf tips, green leaf color and the upper surface of the leaf is older than the lower surface of the leaf. The taproot system where the institutional roots grow continues to become the main root which branches into smaller roots and is slightly hairy all over the surface. This plant reproduces using seeds (Siregar, 2003; Wijaya, 1999).

\subsection{Extraction.}

Taking the active ingredients from a plant can be done by extraction. In this extraction process, the active ingredient will be dissolved by a solvent that matches its polarity. In the extraction process, there is a mass transfer of the active substance that was originally in the cell, pulled by the solvent so that the active substance dissolves in the solvent, generally, the extraction will be better if the surface of the simplicia powder in contact with the solvent is wider (Ansel, 2005). Extraction is the activity of withdrawing soluble chemical substances so that they are separated from insoluble materials with a liquid solvent. The active compounds contained in simplicia can be classified into essential oils, flavonoids, alkaloids, and others. Soft simplicia such as rhizomes and leaves, are easily penetrated by solvents, Therefore, the extraction process does not need to be powdered until smooth. Hard simplicia such as seeds, bark, and root bark are difficult to penetrate by solvents, therefore they need to be powdered until smooth (Directorate General of POM RI, 2000).

The initial process of making the extract is the stage of making dry simplicia powder (pollination) which is made with certain equipment to a certain degree of fineness. This process can affect the quality of the extract based on several things, namely the finer the simplicia powder, the more effective and efficient the extraction process, but the finer the powder, the more technologically complex the equipment for the filtration step and during the use of pollination equipment is where there is movement and interaction with hard objects. (such as metal), then heat will arise which can affect the compound content. In the extraction process, solvents are also used which need to be considered in their selection, such as selectivity, solubility, toxicity, evaporation, economy, environmental friendliness, and safety (Directorate General of POM RI, 2000). According to the Directorate General of POM RI (2000), there are several methods for extraction, namely:

\subsection{Cool way}

Maceration is a simplicia extraction process using a solvent with several times of shaking or stirring at room temperature. The extracting fluid will penetrate the cell wall and enter the cell cavity containing the active substance so that the active substance will dissolve. This method is used for extracting soft simplicia such as leaves, but many also use this method to extract hard simplicia such as roots and cortex because the method of processing and the equipment used is simple and easy to obtain.

Percolation is extraction with a fresh solvent, which is generally carried out at room temperature. The simplicia powder was placed in a cylindrical vessel with a porous partition at the bottom. The extracting liquid flows from top to bottom through the powder, the extracting liquid will dissolve the active substance of the cells that are passed until it reaches a saturated state. To determine the end of percolation, a qualitative examination of the active substance was carried out in the final percolate. The percolation process consists of the material development stage, the intermediate maceration stage, the actual percolation stage (hatching/extract storage), continuously until the extract is obtained.

\section{https://ijhp.net}




\title{
2.5. Hot way
}

\author{
a. reflux
}

Reflux is extraction with a solvent at its boiling point temperature, for a certain time, and a limited amount of solvent which is relatively constant in the presence of reverse cooling. Generally, the process is repeated on the first residue up to 3-5 times so that the extraction process is complete.

\section{b. Soxhletasi}

Soxhletation is extraction using a solvent that is always new which is carried out with a Soxhlet device so that a continuous extraction occurs with a relatively constant amount of solvent in the presence of reverse cooling.

\section{c. Digestion}

Digestion is kinetic maceration (with continuous stirring) at a temperature higher than room temperature, generally carried out at a temperature of $40-50 \mathrm{oC}$.

\section{d. Infundament}

Infancy is the extraction process with water solvent at a temperature of $90 \mathrm{oC}$ for a certain time $(15-20$ minutes).

\section{e. Decoction}

Decoction is an extraction process using water as a solvent at a temperature of $90 \mathrm{oC}$ for 30 minutes.

\subsection{Free Radicals}

Free radicals are molecules or atoms that have one or more unpaired electrons in their outer orbital and can cause damage to biomolecules (Halliwel and Gutteridge, 1989). This causes free radicals to be very reactive and able to take electrons from other molecules, such as proteins and Deoxyribose Nucleic Acid (DNA) (Hafidz, 2003). Free radicals can cause oxidative damage to biological tissues, this damage can cause chronic diseases, such as ischemia, cataracts, cancer, diabetes mellitus, aging, and coronary heart disease (Hiriguchi et al., 1995).Free radicals are formed in two ways, namely endogenously and exogenously. Endogenously, free radicals are generated through biochemical reactions in the body, for example enzymatic oxidation, phagocytosis, electron transport, and ischemic transition metal oxidation. Exogenously, free radicals are generated from the surrounding environment, such as air pollution, food additives, and ultraviolet (UV) radiation.

These exogenous radicals will then enter the body through breathing, digestion, and skin absorption (Amelia, 2006). Free radicals are produced endogenously in cells by mitochondria, plasma membranes, lysosomes, peroxisomes, endoplasmic reticulum, and cell nuclei (Langseth, 1995). Free radicals are generated in the body, usually consisting of reactive oxygen species (ROS) and reactive nitrogen species (RNS). Examples of derivatives of the two species include superoxide radicals $(\mathrm{O} 2 *)$, hydroxyl $\left(\mathrm{OH}^{*}\right)$, peroxyl $\left(\mathrm{ROO}^{*}\right)$, hydrogen peroxide (H2O2-), singlet oxygen (1O2), nitric oxide (NO*), peroxy nitrite (ONOO). - ), and hypochlorous acid (HOCl) (Murray et al., 2003). Atoms or molecules with these free electrons, can be used to generate energy and several physiological functions such as the ability to kill viruses and bacteria. In general, the reaction mechanism for the formation of free radicals consists of three stages, namely initiation, propagation, and termination. The initiation stage is the initial stage of the formation of free radicals. The second stage is propagation, namely the change of a free radical molecule into another form of radical (formation of new free radicals). The last stage is termination.

\subsection{Antioxidant Activity Testing Method}

Measurement of antioxidant activity can be done using several methods, including:

\section{DPPH method (1,1-diphenyl-2-picrylhydrazyl)}

DPPH is a free radical that is stable at room temperature and is often used to assess the antioxidant activity of several compounds or extracts of natural ingredients. The interaction of antioxidants with DPPH 
either by electron transfer or hydrogen radicals in DPPH will neutralize the free radical character of DPPH. If all the electrons in the DPPH free radical are paired, the color of the solution will change from dark purple to bright yellow (Gurav et al., 2007).

\section{Conjugated diene test}

The principle of the conjugated diene test is the formation of hydroperoxides from PUFA (Poly Unsaturated Fatty Acid) causing conjugation of the pentadine structure. This can be in the presence of absorption at 233-234 $\mathrm{nm}$. During the oxidation of linoleic acid, the double bond is transformed into a conjugated double bond which can be characterized by strong UV absorption at a wavelength of $234 \mathrm{~nm}$. The activity is expressed in the concentration of inhibition (IC50) (Pokorny, 2001).

\section{Para-anisidin number}

Para-anisidin is a substance that reacts with an aldehyde to give an absorption product at $350 \mathrm{~nm}$. The number of para-anisidine was defined as the absorbance of the resulting solution of $1 \mathrm{~g}$ of fat in a $100 \mathrm{~mL}$ isoctane solution with para-anisidin. The product formed by reaction with a saturated aldehyde (2-alkane) absorbs more strongly at these wavelengths, and as a result the test is very sensitive to materials undergoing oxidation. Although this test cannot distinguish between volatile or non-volatile substances, it is generally more sensitive to volatile unsaturated aldehydes than saturated aldehydes of the same nature, so it is a suitable means of assessing the presence of secondary oxidation.

\section{Determination of peroxide number}

Peroxide number was measured in the oil sample which added $0.1 \%$ plant extract with BHT antioxidant as a comparison as much as $0.01 \%$, the blank was measured without the addition of extract. Most of the hydrophilic extracts will be difficult to homogenize by this method. Therefore the extract is dissolved in a small amount of ethanol, about $5 \%$ of the mass of the oil and this solution will be mixed into the oil phase with vigorous stirring (Helrich, 1990).

\section{Inhibitory activity of hydroxyl radicals}

The principle of inhibition of hydroxyl radicals is measurement by reacting DMPO (5,5-dimethyl-1pyrroline-N-oxide) and $\mathrm{OH}$ radicals by addition to produce DMPO-OH which is detected by the ESRspectrometer. Parameter settings by measuring the external magnetic field $337.5 \pm 5 \mathrm{mT}$ at a frequency of 100 $\mathrm{kHz}, 10 \mathrm{~mW}$ microwave at $9.43 \mathrm{GHz}$. Ascorbic acid and ethanol were used as controls (Shivaprasad, 2005).

\section{METHODS}

The method used in this research is experimental research. The research included collecting and processing andaliman fruit, making simplicia, making ethanol extracts and examining antioxidant activity tests using the DPPH free radical scavenging method (1,1-diphenyl-2-picrylhydrazil) and antibacterial activity using the minimum inhibitory concentration method.The tools used in this research include laboratory glassware, aluminum foil, blender (National), drying cabinet, electric oven, rough balance (O'haus), digital balance (Vibra), desiccator, stopwatch, porcelain cup, autoclave (Webeco), stir bar, beaker, Laminar Air Flow Cabinet (Astec HLF I200L), blender (Miyako), bunsen, petri dish, porcelain dish, erlenmeyer, measuring cup, incubator (Memmert), caliper, ose needle, sterile cotton swab and knife, rotary evaporator (Heidolph VV-300), UV/Vis spectrophotometer (Shimadzu UV-1800).

Sampling was carried out purposively, that is, without comparing with the same material from other areas. The sample used in this study was andaliman fruit (Zanthoxylum acanthopodium DC.) purchased from Onan Rungu village, Samosir Regency, North Sumatra Province.Extraction was carried out by maceration using $96 \%$ ethanol as solvent. Andaliman fruit simplicia powder as much as $500 \mathrm{~g}$ with a suitable fine degree was put into a vessel, then poured with 75 parts of $96 \%$ ethanol, then covered and left for 5 days, protected from light while stirring occasionally every day. After 5 days, then filtered, squeezed dregs. The dregs were washed with

\section{https://ijhp.net}


sufficient solvent, stirred and filtered to obtain 100 parts. Collect the maserate in a closed vessel, allow it to cool and protect it from light for 2 days, then pour it in, then evaporate the solvent using a rotary evaporator at a temperature of $40-50_{-} \mathrm{C}$, then concentrated on a water bath until a thick extract was obtained (Directorate General of POM RI, 1979).

IV. ANALYZE AND RESULT.

\subsection{Andaliman Fruit Extract Phytochemical Screening Test Results}

Phytochemical screening test was carried out with the aim of identifying and identifying the components of bioactive compounds contained in the andaliman fruit extract. The components of the active compounds identified include: alkaloids, steroids/triterpenes, saponins, tannins, flavonoids and glycosides. The results of screening of andaliman fruit extracts extracted using ethylacetate solvent can be seen in Table 1

Table 1. Phytochemical Screening Test Results Andaliman Fruit Extract

\begin{tabular}{l|c}
\hline \multicolumn{1}{c|}{ Bioactive Compound } & Andaliman Fruit Extract \\
\hline Alkoloid & + \\
Flavonoids & + \\
Saponins & + \\
Tannins & + \\
Steroids/Triterpenoids & - \\
Glycoside & + \\
\hline
\end{tabular}

Based on the results of the qualitative analysis of the active components of the andaliman extract extracted with ethylacetate solvent above, it shows that the andaliman fruit extract with ethylacetate solvent contains almost all secondary metabolites, except steroids/triterpenoids. Secondary metabolite compounds found in andaliman extract that act as antimicrobials are alkaloids, flavonoids, glycosides, saponins and tannins. Previous studies regarding the extraction of andaliman (Parhusip, 2016), there are 3 types of solvents used; hexane, methanol, ethylacetate. The results of the screening tests carried out showed that the andaliman extract using ethylacetate as a solvent contained almost all secondary metabolites of alkaloids, flavonoids, glycosides, saponins, steroids, except tannins. While the research conducted by Sihotang et al.

According to Robinson (1995), alkaloids have the ability as antibacterial and pharmacological effects as analgesics and anesthetics. The mechanism of inhibition of bacteria by this compound is thought to be by interfering with the peptidoglycan constituent components in bacterial cells so that the cell wall layer is not fully formed and causes cell death. According to Safitri (2010), saponins have potential as antimicrobial compounds because of their ability to reduce the permeability of bacterial cell walls so that they can enter the bacterial cytosol and inhibit their growth.Other metabolites found in andaliman extract are tannins. According to research Karlina et al. (2013), tannins are phenolic compounds that cause damage to cell wall polypeptides, the mechanism for inhibiting tannins occurs by lysing bacterial walls due to saponins and flavonoids, causing tannin compounds to easily enter bacterial cells and coagulate bacterial cell protoplasm. . In addition, according to Robinson (1995), the mechanism of action of tannins as antibacterial is to inhibit the enzyme reverse transcriptase and DNA topoisomerase so that bacterial cells cannot be formed.

\subsection{Andaliman Fruit Ethanol Extract Antioxidant Activity Test Results}

Testing the antioxidant activity of the ethanol extract of andaliman fruit with the DPPH method using a UV-VIS spectrophotometer with a wavelength of $516 \mathrm{~nm}$. The following are the results of the antioxidant activity test, which can be seen in Table 4.1 below:

Table 2. Andaliman Fruit Ethanol Extract Measurement Results

\begin{tabular}{|l|l|l|l|}
\hline No & Concentration $(\mathrm{ppm})$ & Absorbance & \% Damping \\
\hline 1. & Blank & 0.890 & 0 \\
\hline 2. & $100 \mathrm{mg} / \mathrm{mL}$ & 0.105 & 88.2397 \\
\hline 3. & $50 \mathrm{mg} / \mathrm{mL}$ & 0.120 & 86.4794 \\
\hline
\end{tabular}




\begin{tabular}{|l|l|l|l|}
\hline 4. & $25 \mathrm{mg} / \mathrm{mL}$ & 0.388 & 56.4419 \\
\hline 5. & $12.5 \mathrm{mg} / \mathrm{mL}$ & 0.585 & 34.3071 \\
\hline
\end{tabular}

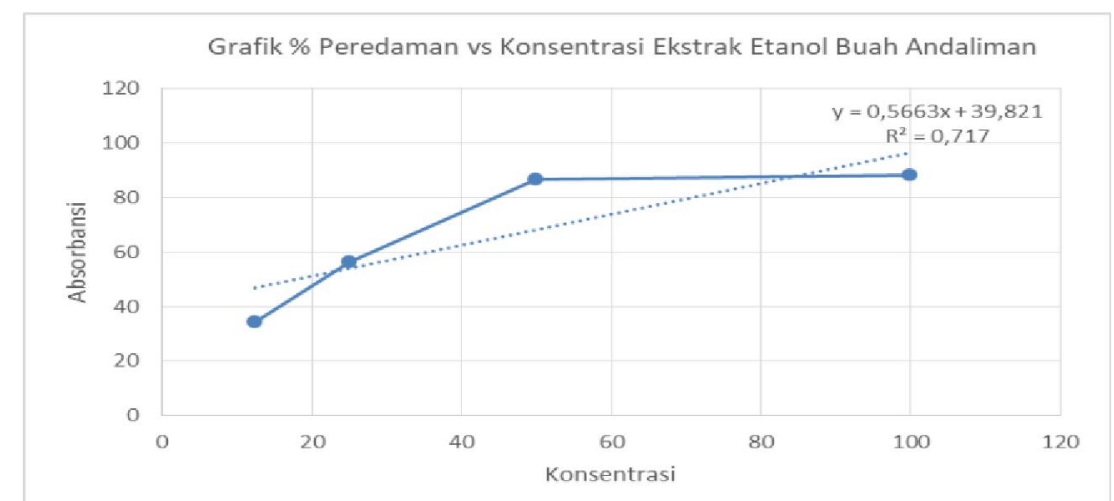

Fig 1. Graph of \% Attenuation vs Concentration of Andaliman Fruit Ethanol Extract

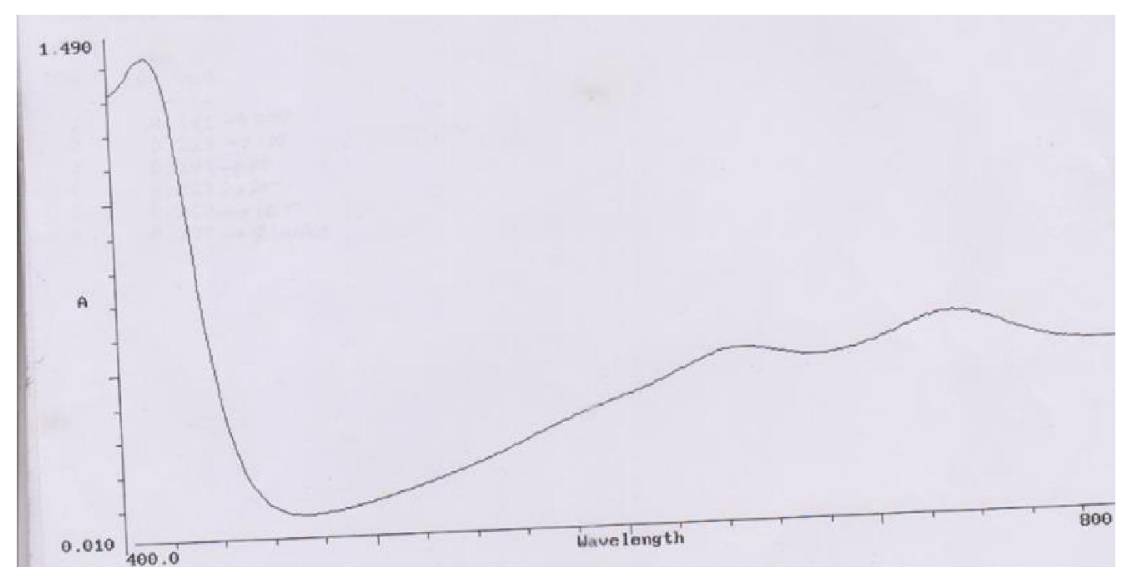

Fig 2. Maximum Wavelength Graph $516 \mathrm{~nm}$

Based on Table 2 and Figure 1 of the regression equation $(y=0.5663 x+39.821)$, the IC50 value of $17.9745 \mathrm{mg} / \mathrm{mL}$ can be classified as a very strong antioxidant activity. The level of strength of antioxidant compounds using the DPPH method can be classified in table 4.2. The IC50 value was obtained based on the linear regression equation obtained by plotting the concentration of the test solution (ppm) as the X-axis and the percent reduction value as the $\mathrm{Y}$-axis which was used for the antioxidant activity parameters. The antioxidant activity test was carried out using the DPPH method using a UV-Visible spectrophotometer. Butanol extract of andaliman fruit contains a class of phenolic compounds that act as antioxidants (Harborne, 1996). Based on the results obtained showed a decrease in the absorbance of DPPH with the addition of ethanol extract of andaliman fruit compared to the blank solution without the addition of ethanol extract of andaliman fruit. The decrease in absorbance value occurs because the test solution dampens DPPH and attenuation occurs due to electron transfer of antioxidant hydrogen atoms to DPPH.The results of the measurement of the diameter of the clear zone of antibacterial activity of the long bean leaf methanol extract against the bacteria Stapylococcus aureus and Stapylococcus epidermidis can be seen in tables 3 and 4 at below:

Table 3. Results of Antibacterial Activity of Andaliman Fruit Ethanol Extract for Stapylococcus aureus bacteria

\begin{tabular}{|l|l|l|l|l|l|}
\hline Concentration $(\mathrm{mg} / \mathrm{mL})$ & P1 & P2 & P3 & X & SEM \\
\hline 300 & 10.3 & 10.1 & 10.1 & 10,17 & 0.12 \\
\hline 200 & 9.6 & 9.4 & 9.7 & 9.57 & 0.15 \\
\hline
\end{tabular}

https://ijhp.net 
International Journal of Health and Pharmaceutical

\begin{tabular}{|l|l|l|l|l|l|}
\hline 100 & 8.7 & 8.4 & 8.4 & 8.50 & 0.17 \\
\hline 50 & 7.9 & 8.1 & 7.9 & 7.97 & 0.12 \\
\hline 25 & 7 & 6.9 & 6.7 & 6.87 & 0.15 \\
\hline 12.5 & 6.4 & 6.5 & 6.3 & 6.40 & 0.10 \\
\hline 6.25 & 6 & 6 & 6 & 6.00 & 0.00 \\
\hline K- & 6 & 6 & 6 & 6.00 & 0.00 \\
\hline
\end{tabular}

Table 4. Results of Antibacterial Activity Test of Andaliman Fruit Ethanol Extract Stapylococcus epidermidis bacteria

\begin{tabular}{|l|l|l|l|l|l|}
\hline Concentration $(\mathrm{mg} / \mathrm{mL})$ & P1 & P2 & P3 & X & SEM \\
\hline 300 & 11.8 & 11.6 & 10.3 & 10,80 & 0.20 \\
\hline 200 & 9.6 & 6.5 & 9.2 & 8.73 & 0.32 \\
\hline 100 & 8 & 8.2 & 8.6 & 8.27 & 0.31 \\
\hline 50 & 7.7 & 7.3 & 8.3 & 7.77 & 0.50 \\
\hline 25 & 6.9 & 6.7 & 6.6 & 6.73 & 0.15 \\
\hline 12.5 & 6.4 & 6.3 & 6.3 & 6.33 & 0.06 \\
\hline 6.25 & 6 & 6 & 6 & 6.00 & 0.00 \\
\hline K- & 6 & 6 & 6 & 6.00 & 0.00 \\
\hline
\end{tabular}

'Based on Tables 3 and 4 the antibacterial activity test aims to determine the potential for bacterial activity in the test sample. The antibacterial activity test method used in this study was the agar diffusion method, in this method the antibacterial activity of the test sample was indicated by the formation of an inhibitory zone around the paper disc. A paper disc containing an antimicrobial agent is placed on an agar medium that has been implanted with microorganisms. The clear area indicates the inhibition of the growth of microorganisms by antimicrobial agents on the surface of the agar media (Pratiwi, 2008). In this study, pathogenic bacteria were used, namely Stapylococcus aureus and Stapylococcus epidermidis. The results of the antibacterial activity test of the ethanolic extract of andaliman fruit showed that the extract had antibacterial activity in the moderate category at a concentration of $300 \mathrm{mg} / \mathrm{ml}$ with an inhibition zone of $10.17 \mathrm{~mm}$ for Staphylococcus aureus bacteria and a moderate category for Staphylococcus epidermidis bacteria with an inhibition zone of $10.80 \mathrm{~mm}$. The difference in the diameter of the inhibition zone between the two bacteria indicated that there was a difference in the sensitivity of the extract to the test microbes. Antimicrobial compounds can cause damage to cell walls and damage to cell membranes in the form of denaturation of proteins and fats that make up cell membranes. The ethanol extract of andaliman fruit is effective in inhibiting the growth of gram-positive bacteria Stapylococcus aureus and Stapylococcus epidermidis,

Based on the table obtained Pathogenic bacterial strains were used for antibacterial screening of andaliman fruit ethanol extract from the maceration extraction process, namely: Staphylococcus aureus and Staphylococcus epidermidis. inhibits bacterial growth. growth and number of bacteria $<10$ colonies. MIC is the minimum concentration of antimicrobial substances that can inhibit bacterial growth after 24 hours of incubation and it is not known that there are bacterial colonies that grow by observing the number of bacterial colonies that grow (Tortora et al., 2010). The inhibition zone diameter of $5 \mathrm{~mm}$ or less was categorized as weak, the inhibition zone diameter of $5-10 \mathrm{~mm}$ was categorized as moderate, the inhibition zone diameter of 10-20 $\mathrm{mm}$ was categorized as strong and the inhibition zone of $20 \mathrm{~mm}$ or more was categorized as very strong (Boateng and Diunase., 2015).This study showed that the higher the concentration of the extract, the greater the number of antibacterial compounds released, thus facilitating the penetration of these compounds into cells. In other words, the higher the concentration of the extract and the longer the contact time, the more active the antibacterial

\section{https://ijhp.net}


activity. consists of a layer of peptidoglycan which is more than gram-negative whose outer membrane consists of lipopolysaccharides, namely lipids, polysaccharides and proteins (Pratiwi, 2008).

The cell wall of gram-negative bacteria contains far less peptidoglycan than gram-positive bacteria so that the permeability of gram-positive bacteria is lower than that of gram-negative bacteria. With low permeability, the active substance from the methanol extract of loning plant leaves will have difficulty penetrating the cell membrane of gram-positive bacteria so that the effect of bacteria is less than optimal on growing bacterial cells and causes cell death. Flavonoid compounds have the ability to form complexes with bacterial cell proteins through hydrogen bonds. The structure of the cell wall and cytoplasmic membrane of bacteria containing proteins becomes unstable because the protein structure of bacterial cells is damaged due to hydrogen bonds with flavonoids, so that bacterial cell proteins lose their biological activity. As a result,

\section{CONCLUSION}

Based on the results of the research that has been done, it can be concluded that:

a. Andaliman fruit ethanol extract sample has antioxidant activity with an IC50 value of $17.9745 \mathrm{mg} / \mathrm{mL}$

b. The ethanol extract of andaliman fruit is a sample with very strong antioxidant activity because it has an IC50 value with a concentration of $12.5-100 \mu \mathrm{g} / \mathrm{mL}$ and a strong antioxidant activity with an IC50 value with a concentration of $25-100 \mathrm{~g} / \mathrm{mL}$.

c. The ethanol extract of andaliman fruit can inhibit Staphylococcus aureus and Staphylococcus epidermidis, effective at a concentration of $300 \mathrm{mg} / \mathrm{ml}$ with inhibitory diameters of $10.17 \mathrm{~mm}$ and $10.80 \mathrm{~mm}$, respectively.

\section{REFERENCES}

[1] Amelia G. 2006. Potential of pearl grass (Hedyotis corimbosa Lam.) as a natural antioxidant. Essay. Bogor: Faculty of Mathematics and Natural Sciences, Bogor Agricultural University. Page 40

[2] Anorital., Andayasari, L. 2011. Epidemiological study of digestive tract infectious diseases caused by amoeba in Indonesia. Health Research and Development Media. 21(1): 1-2.

[3] Ansel, HC (2005). Introduction to Pharmaceutical Dosage Forms. Translator: Farida Ibrahim. Fourth Edition. Jakarta: University of Indonesia (UIPress) Publisher. Pages 607-609.

[4] Buck, DF 1991. Antioxidants. In: J. Smith, editor. Food Additive User's Handbook. Blackie Academic and Professional. Glasgow-UK

[5] Cui XG; Zhao, QJ; Chen, QL; Xu, L.; Song, Y.; Jin, YS and Xu, DF (2008). Two New Benzophenanthridine Alkaloids from Zanthoxylum nitidum. Helvetica Chimica Acta. 91(1): 155-158.

[6] Chen, JJ; Chen, PH; Liao, CH; Huang, SY and Chen, IS (2007). New Phenylpropenoids, Bis (1-phenylethyl) phenols, Bisquinolinone Alkaloids, and Anti-inflammatory Constituents from Zanthoxylum integrifoliolum.

Journal of Natural Products.70:1444-1448.

[7] Day, RA, and Underwood, AL 1986. Quantitative Chemical Analysis. Edition IV. Translation of Sopyan, I. Jakarta: Erlangga Publisher. Case. 382.

[8] Indonesian Ministry of Health. 1995. Indonesian Medical Materials. Volume VI. Jakarta: Ministry of Health of the Republic of Indonesia. Pages 300-306, 321, 325, 333-337.

[9] Difco Laboratories. 1977. Difco Manual of Dehydrated Culture Media and Reagents for Microbiology and Clinical Laboratory Procedures. Ninth edition. Detroit Michigan: Difco Laboratories. Pages 29, 32.

[10] Directorate General of POM RI. 1979. Indonesian Pharmacopoeia. Third Edition. Jakarta: Indonesian Ministry of Health. Case. 100, 649-653, 659, 696, 733, 772.

[11] Directorate General of POM. 1995. Indonesian Pharmacopoeia. Fourth Edition. Jakarta: Ministry of Health of the Republic of Indonesia. Pages 7, 891 - 898, 1035.

[12] Directorate General of POM RI. (2000). General Standard Parameters of Medicinal Plant Extracts. Jakarta: Ministry of Health of the Republic of Indonesia. Pages 1-11.

[13] Dwidjoseputro. 1978. Fundamentals of Microbiology. Jakarta: Bridge. Pages 81 82, 84.

[14] Fernandes, CC; Vieira, PC; da Silva, VC; Dall'Oglio, EL; da Silva, LE and de Sousa, PT (2009). 6-Acetonyl-Nhttps://ijhp.net 
methyl-dihydrodecarine, a New Alkaloid from Zanthoxylum riedelianum. Journal of the Brazilian Chemical Society. 20(2): 379-382.

[15] Gandjar, IG, Rohman, A. 2007. Analytical Pharmaceutical Chemistry. Yogyakarta: Student Library. page 222.

[16] Gurav, S., Deshkar, N., Gulkari, V., Duragkar N., Patil, A.2007. Free Radical Scavenging Activity of Polygala Chinensis Linn. Pharmacologyline. 2(3): 245-253.

[17] Hafidz, AF 2003. Anti-free radical activity of DPPH methanol fraction Fagreaea auriculata and Fagreaea ceilanica. Pharmacy Magazine. Airlangga III: April 1, 2003

[18] Halliwell B., Guteridge JMC. 1986. FreeRadical in Biology and Medicine. Clarendon Press, New York: Oxford University Press. Page 384-385

[19] Harborne, JB (1996). Phytochemical Methods, A Guide to Modern Ways of Analyzing Plants. Kosasih Padmawinata Translation. Edition II. Bandung: ITB Press. Pg 147.

[20] Harborne, JB 2003. Phytochemical Methods: A Guide to Modern Methods of Analysis Plant. Edition II. Bandung Institute of Technology. Bandung

[21] Helrich, K. 1990. AOCS Official Methods of Analysis. First Edition. Arlington: AOAC. 956.

[22] Hernani, Rahardjo, M. 2005. Antioxidant Efficacious Plants. Jakarta: Self-Help Spreader. page 17.

[23] Hiriguchi, H., Saito, T., Okamura, N., Yagi, A. 1995. Inhibition of lipid peroxidation and superoxide generation by diterpenoids from Rasamarinus officinalis. Planta Medica 61: 333-336.

[24] Hu, U Zhang, WD; Liu, RH; Zhang, C.; Shen, YH; Li, HL; Liang, MJ and Xu, XK (2006). Benzophenanthridine alkaloids from Zanthoxylum nitidum (Roxb.) DC, and their analgesic and anti-inflammatory activities. Chem Biodivers. 3(9): 990-5.

[25] Hynniewta, SR, Kumar, Y. (2008). Herbal Remedies Among The Khasi Traditional Healers And Village Folks In Meghalaya. Indian Journal of Traditional Knowledge. 7(4): 481-586.

[26] Ionita P. (2003). Is DPPH Stable Free Radical a Good Scavenger for Oxygen Active Species. Romania.

[27] Jawetz, E., Melnick, JL, and Adelberg, EA 2001. Medical Microbiology. XXII Edition. Jakarta: Salemba Medika Publisher. Pages 205-209.

[28] Kumalaningsih, S. 2006. Natural Antioxidants. Surabaya: Trubus Agrisarana. page 24.

[29] RE, and Junie, S. (2015). The Indonesian Zanthoxylum acanthopodium DC. : Chemical And Biological Values. International Journal of PharmTech Research, 8(6) : 313-321. 